Research Paper

\title{
Interleukin-8 Regulates Endothelial Permeability by Down-regulation of Tight Junction but not Dependent on Integrins Induced Focal Adhesions
}

\author{
Hongchi Yu, Xianliang Huang, Yunlong Ma, Min Gao, Ou Wang, Ting Gao, Yang Shen ${ }^{\bowtie}$ and Xiaoheng \\ $\mathrm{Liu}^{凶}$ \\ Institute of Biomedical Engineering, School of Preclinical and Forensic Medicine, Sichuan University, Chengdu 610041, China.
}

$\triangle$ Corresponding author: Dr. Yang Shen and Dr. Xiaoheng Liu, Institute of Biomedical Engineering, School of Preclinical and Forensic Medicine, Sichuan University, Chengdu 610041, China. Email: shenyang24@126.com and liuxiaohg@scu.edu.cn.

() Ivyspring International Publisher. This is an open-access article distributed under the terms of the Creative Commons License (http://creativecommons.org/ licenses/by-nc-nd/3.0/). Reproduction is permitted for personal, noncommercial use, provided that the article is in whole, unmodified, and properly cited.

Received: 2013.06.24; Accepted: 2013.08.29; Published: 2013.09.23

\begin{abstract}
Interleukin-8 (IL-8) is a common inflammatory factor, which involves in various non-specific pathological processes of inflammation. It has been found that increased endothelial permeability accompanied with high expression of IL-8 at site of injured endothelium and atherosclerotic plaque at early stages, suggesting that IL-8 participated in regulating endothelial permeability in the developing processes of vascular disease. The purpose of this study is to investigate the regulation effects of IL-8 on the vascular endothelial permeability, and the mRNA and protein expression of tight junction components (i.e., ZO-I, Claudin-5 and Occludin). Endothelial cells were stimulated by IL- 8 with the dose of 50,100 and $200 \mathrm{ng} / \mathrm{mL}$, and duration of 2, 4, 6, 8h, respectively. The mRNA and protein expression level of tight junction components with IL-8 under different concentration and duration was examined by RT-PCR and Western blot, respectively. Meanwhile, the integrins induced focal adhesions event with IL-8 stimulation was also investigated. The results showed that IL-8 regulated the permeability of endothelium by down-regulation of tight junction in a dose- and time-dependence manner, but was not by integrins induced focal adhesions. This finding reveals the molecular mechanism in the increase of endothelial cell permeability induced by IL-8, which is expected to provide a new idea as a therapeutic target in vascular diseases.
\end{abstract}

Key words: Endothelial permeability; IL-8; Tight junction; Occludin; Claudin-5; ZO-1.

\section{Introduction}

Vascular endothelium is a semipermeable membrane, which could separate the inner and outer of vessel and regulate the exchange of dissolved gases, ions and solutes between the inner and outer of vascular endothelium as an important barrier function [1]. The maintenance by the endothelium of a semi-permeable barrier is particularly essential for establishing the transendothelial protein gradient and maintaining the normal physiological functions of organs. The elevated permeability of endothelium means that it in part lost semipermeable characteristics, which is a crucial pathological phenomenon in- volved in the development of diseases, including heart and lung edema [2], tumor angiogenesis [3] and shock [4-5]. Moreover, the loss of endothelial barrier function is the hallmark of inflammatory diseases such as atherosclerosis [6].

The dynamic equilibrium between cell adhesion and cytoskeleton contraction plays an important role in maintaining the normal function of endothelial permeability. It is known that intercellular junction, as an important structural basis of endothelial cell permeability, is mediated by adhesion structures, which can be divided into tight junction, gap junction and 
adherent junction [7]. The function of gap junction involved in transmitting biochemical information among adjacent endothelial cells, while tight junction and adherent junction contributed to macromolecules transport.

Tight junction is located in the top side of the gap of adjacent cells, which is formed with a variety of proteins, and plays a critical role in the maintenance of stable internal environment and the normal functions of body [7]. Changes in vascular permeability may result from alterations of the tight junction components. Tight junction is composed of a combination of more than 40 proteins including the transmembrane proteins Occludin, the Claudin family, the junction adhesion molecule (JAM) family, and peripheral membrane-associated Zonula occludens (ZO) family [8]. Evidences have been provided for the presence of Occludin, Claudin-5, ZO-1, and JAM-A in vascular endothelium [9-11]. Therefore, changes in Occludin, Claudin-5, and ZO-1 likely contribute to alterations in vascular endothelial permeability in response to stimulation of inflammatory cytokines. On the other hand, the barrier function of tight junctions regulates the passage of ions, water, and various macromolecules, even if cancer cells, through paracellular spaces to maintain tissue homeostasis. The vascular endothelium is a monolayer comprising of not only endothelial cells but also extracellular matrix (ECM) proteins, indicating that under normal conditions the permeability of the endothelium depends on the combined properties of the cell layer and the ECM barriers in series [12]. ECM proteins, including fibronectin $(\mathrm{FN})$, laminin $(\mathrm{LN})$, vitronectin $(\mathrm{VN})$ and collagens (Col), bind to extracellular domains of integrin a subunits receptors on cell membrane, and transduce signals from extracellular stimuli to intracellular events. Around activated integrin clusters on the cell membrane, cytoskeletal proteins (Talin, Paxillin, Vinculin and so on) as the ligands of integrin $\beta$ cytoplasmic tails, assemble together to form focal adhesion (FA) plaques and provide enough supports for cell adhesion on the substrate. Vinculin frequently links adhesion receptors (e.g. integrins) to the contractile actin-myosin cytoskeleton by binding either talin through its amino-terminal globular head domain, or Paxillin through its rod-like tail domain [13]. Therefore, both cell-cell junction and cell-ECM adhesion likely contribute to endothelial barrier function [1].

The endothelial permeability is regulated by a variety of chemical and biological factors. Of these factors, the adhesion molecules, MCP-1, IL-8 and other chemotactic cytokines play key roles. IL-8 is a chemokine that increases endothelial permeability during early stages of angiogenesis, which involved in various non-specific inflammation pathological processes [14]. Some reports have proved that IL-8 has extensive functions in defensive reaction, immune reactions as well as inflammation [15]. Preliminary studies showed that IL-8 could activate the vascular endothelial cells and induce migration behaviors [16-17], and there was a high expression of IL-8 at endothelial cell injury and the atherosclerotic plaque [18]. It has been reported that IL-8 induced endothelial permeability required the activation of vascular endothelial growth factor receptor-2 (VEGFR2) [19]. Therefore, the question raised to us is how tight junction proteins would be changed involved in IL-8 induced permeability.

In this study, endothelial cells were stimulated by IL- 8 with the doses of 50,100 and $200 \mathrm{ng} / \mathrm{mL}$ for 2 , 4,6 and $8 \mathrm{~h}$, respectively. The changes of tight junction proteins (Occludin, Claudin-5 and ZO-1) in IL-8 stimulated endothelial cells were examined. In addition, the proteins expression of integrins ( $\alpha 2, a 5, \beta 1$ and $\beta 3$ subunits) and focal adhesion complexes (Talin, Vinculin and Paxillin) were examined to determine if integrins and their downstream signals participate in permeability changes mediated by IL-8.

\section{Materials and Methods}

Human vascular endothelial cell lines, EA.hy926 cells (provided by Hematology Research Institute of Jiangsu Province, China) were used in this study, which are hybridoma cell lines between human umbilical vein endothelial cells (HUVECs) and the epithelioma A549 cells, and retain most features of HUVECs, including the expression of endothelial adhesion molecules and human factor VIII-related antigen. EA.hy926 cells were cultured in RPMI1640 medium (Invitrogen Company, USA) supplemented with 10\% fetal bovine serum (FBS, Hangzhou Sijiqing Biological Engineering Materials Co., Ltd., China), $20 \mathrm{mmol} / \mathrm{L}$ HEPES (Sigma, USA), 2\% $\mathrm{NaHCO}_{3}$ and 2\% HAT (Sigma, USA). The cells were maintained in a $5 \% \mathrm{CO}_{2}$ incubator at $37^{\circ} \mathrm{C}$.

Human IL-8 was purchased from Millipore Chemicon Corporation (Billerica, MA, USA). The primary antibodies of tight junction proteins including anti-Claudin-5 (H-52) rabbit polyclonal $\mathrm{Ab}$ (sc-28670), anti-Occludin (F-7) mouse monoclonal Ab (sc-271842) and anti-ZO-1 (H-300) rabbit polyclonal $\mathrm{Ab}$ (sc-10804); the primary antibodies of integrins subunits, including anti-integrin a2 (C-9) mouse monoclonal $\mathrm{Ab}$ (sc-74466), anti-integrin a5 (A-11) mouse monoclonal $\mathrm{Ab}$ (sc-166665), anti-integrin $\beta 1$ (A-4) mouse monoclonal Ab (sc-374429), anti-integrin $\beta 3$ (B-7) mouse monoclonal $\mathrm{Ab}$ (sc-466655); the primary antibodies of focal adhesion complexes, including anti-Vinculin (G-11) mouse monoclonal Ab 
(sc-55465), anti-Talin (8D4) mouse monoclonal $\mathrm{Ab}$ (sc-59881), anti-Paxillin (D-9) mouse monoclonal $\mathrm{Ab}$ (sc-365174) and anti- $p$ Paxillin (Tyr 118) rabbit polyclonal Ab (sc-101774), E-cadherin (67A4) mouse monoclonal $\mathrm{Ab}$ (sc-21791) and N-cadherin (H-63) rabbit polyclonal $\mathrm{Ab}$ (sc-7939) were purchased from Santa Curz ${ }^{\mathrm{TM}}$ Biotechnology, Inc (CA, USA). The peroxidase-conjugated goat anti-mouse IgG and goat anti-rabbit IgG (secondary antibodies) were purchased from Dingguo Biotechnology Co., LTD (Beijing, China).

\section{Permeability assay by Transwell}

The endothelial permeability assay was performed according to previous report [20]. Briefly, cells were cultured on Matrigel-coated transwell of $0.4 \mu \mathrm{m}$ pore size and then placed in 24-well culture plates for grow $4-5$ days at $100 \%$ confluent. Cells were washed with phosphate-buffered saline (PBS) for 3 times. To examine the effects of different concentrations and durations of IL-8 on endothelial permeability, the groups were designed as follows: 50, 100 and 200 $\mathrm{ng} / \mathrm{ml}$ IL-8 treated endothelial cells for $4 \mathrm{~h}$ and 100 $\mathrm{ng} / \mathrm{ml} \mathrm{IL-8}$ treated cells for 2, 4 and $8 \mathrm{~h}$, respectively. Then FITC-labeled bovine serum albumin (Sigma, USA) was added into the top (luminal) chamber at a concentration of $1 \mathrm{mg} / \mathrm{ml}$, and continued to culture for $1 \mathrm{~h}$. The transwell chambers were removed and 70 $\mu \mathrm{l}$ culture medium was taken out from each bottom chambers, and fluorescence intensity was quantified using a fluorimeter (TBS-380 mini-FLuorometer systems, Turner BioSystems ${ }^{\mathrm{TM}}$, USA), with excitation at $485 \mathrm{~nm}$ and emission at $535 \mathrm{~nm}$, to provide an indicator of relative endothelial permeability. Sample readings were converted with the use of a standard curve to albumin concentration. These concentrations were then used in the following equation to determine the permeability coefficient of albumin $\left(P_{\mathrm{a}}\right)$,

$$
P_{a}=\frac{\left[C_{a}\right]}{t} \times \frac{1}{S} \times \frac{V}{\left[C_{l}\right]}
$$

where $\left[C_{a}\right]$ was the abluminal concentration; $t$ was time (s); $S$ was the area of membrane $\left(\mathrm{cm}^{2}\right) ; V$ was the volume of luminal chamber, and $\left[C_{l}\right]$ was the luminal concentration [20].

\section{Morphologic observation of IL-8 induced en- dothelial permeability}

EA.hy926 cells with almost $100 \%$ confluence were treated by IL- 8 with different concentrations ( 0 $\mathrm{ng} / \mathrm{mL}$ as controls, 50, 100 and $200 \mathrm{ng} / \mathrm{mL}$ ) and durations $(100 \mathrm{ng} / \mathrm{ml} \mathrm{IL-8} \mathrm{treated} \mathrm{for} \mathrm{2,} \mathrm{4,} 6$ and $8 \mathrm{~h}$ ), respectively. At each time point, the cells were washed twice with PBS, and fixed with $4 \%$ paraform- aldehyde for $15 \mathrm{~min}$ at room temperature. Cells were incubated in the BODIPY FL Phallotoxins solution (with 1:100 dilution, Invitrogen ${ }^{\mathrm{TM}}$, USA) for $90 \mathrm{~min}$, the DAPI $\left(4^{\prime}, 6^{\prime}\right.$ - diamidino-2-phenylindole) with 1:800 dilution was added for nuclei staining for 30 min. Each step was followed by washing with PBS for $5 \mathrm{~min}$ for less three times. Using a laser scanning confocal microscope (Leica TCS SP5, Germany), the morphologies and gaps among all groups indicated endothelial permeability were examined. For transmission electron microscope (TEM) observation, samples were treated by IL- 8 and gently collected by a plastic cell scrapper (Corning, USA) to maintain origin cell-cell junction. The samples were centrifuged at $1,500 \mathrm{rpm}$ for $10 \mathrm{~min}$, fixed with $0.5 \%$ glutaraldehyde, and stored at $4^{\circ} \mathrm{C}$ for $10 \mathrm{~min}$. Then, the samples were centrifuged again at 12,000 rpm for $10 \mathrm{~min}$; the supernatant was discarded and 3\% glutaraldehyde was added slowly. All samples were fixed by $1 \%$ $\mathrm{OsO}_{4}$, dehydrated by different concentration of acetone, embedded by epoxy resin (Epon812), cut into slices and doubled dyed by uranyl acetate and lead citrate. The micro-structure of cell-cell junctions were observed by TEM (H-600IV, Japan).

\section{Reverse transcription polymerase chain reac- tion (RT-PCR)}

The mRNA expressions of occludin, claudin- 5 and ZO-1 were semi- quantitatively determined by RT-PCR assays. Total RNA was extracted from the cells by using the TRIzol reagent (Invitrogen Company, USA). First-strand cDNA was synthesized by using the Revert Aid ${ }^{\mathrm{TM}}$ Frist Strand cDNA Synthesis System (Fermentas). RT-PCR was carried out by using the TaKaRa One Step RNA PCR Kit (AMV) (TaKaRa, Dalian, China) according to the manufacturer's instructions. To obtain the relative quantitative values for gene expression, $\beta$-actin was used as the endogenous control. Sequences of the primers used for RT-PCR listed in Table 1 were designed by Invitrogen Company (USA). The reaction conditions were as follows: incubation at $95^{\circ} \mathrm{C}$ for $3 \mathrm{~min}$, denaturation at $95^{\circ} \mathrm{C}$ for $30 \mathrm{~s}$, annealing at $53^{\circ} \mathrm{C}$ (occludin), $56^{\circ} \mathrm{C}$ (claudin-5), $52^{\circ} \mathrm{C}(\mathrm{ZO}-1)$ or $55^{\circ} \mathrm{C}$ ( $\beta$-actin) for $30 \mathrm{~s}$, and polymerization at $72^{\circ} \mathrm{C}$ for 60 s for 22 cycles, followed by a final extension at $72^{\circ} \mathrm{C}$ for $10 \mathrm{~min}$. The PCR products were visualized by electrophoresis on a $1 \%$ agarose gel in $1 \times$ Tris-acetate-EDTA (TAE) buffer after staining with $0.5 \mu \mathrm{g} \mathrm{ml} \mathrm{m}^{-1}$ ethidium bromide. All electrophoresis images were quantitatively analyzed by using Gel-Pro Analyzer 4.5 software and normalized to their respective $\beta$-actin values. 
Table I Oligonucleotide primers used for RT-PCR analysis

\begin{tabular}{lll}
\hline Target transcript & Primer sequence $\left(5^{\prime}-3^{\prime}\right)$ & Product size $(\mathrm{bp})$ \\
\hline Occludin (forward) & 5'-TTGGGACAGAGGCTATGG-3' $^{\prime}$ & 623 \\
Occludin (reverse) & $5^{\prime}$-ACCCACTCTTCA ACATTGGG-3' & 203 \\
Claudin-5(forward) & $5^{\prime}$ - CCTTCCTGGACCACAACATC -3' & \\
Claudin-5 (reverse) & $5^{\prime}$ - GCCGGTCAAGGTAACAAAGA -3' & 254 \\
ZO-1 (forward) & $5^{\prime}$ - GCTAAGAGCACAGCAATGGA -3' & 205 \\
ZO-1(reverse) & $5^{\prime}$ - GCATGTTCAACGTTATCCAT -3' & \\
$\beta$-actin (forward) & $5^{\prime}$ - TGACGTGGACATCCGCAAAG -3' & \\
$\beta$-actin (reverse) & $5^{\prime}$ - CTGGAAGGTGGACAGCGAGG -3' & \\
\hline
\end{tabular}

\section{Western blotting assay}

EA.hy926 cells were washed twice with PBS on the ice, then treated with $200 \mu$ l RIPA buffer, containing 1\% Phenylmethanesulfonyl fluoride (PMSF) and Complete ${ }^{\mathrm{TM}}$ protease inhibitor cocktail (Roche Molecular Biochemicals, Indianapolis). 30 min later, the lysed cells were centrifuged at 12,000 rpm for 5 min, and the supernatant was collected. Total protein content of the lysates was determined using a BCA (bicinchoninic acid) Protein Assay Kit (Beyotime Institute of Biotechnology, China). Proteins in the lysates were subjected to SDS-PAGE electrophoresis and transferred to PVDF membranes. Membranes were blocked in 1\% BSA at room temperature for less $2 \mathrm{~h}$, and then incubated with the diluted primary antibody in TBST buffer at $4^{\circ} \mathrm{C}$ for overnight. After incubation, membranes were washed three times for 5 min at room temperature with TBST buffer and incubated with the appropriate peroxidaseconjugated secondary antibody (in TBST, 1:8000) for 1 $\mathrm{h}$. Membranes were then rinsed three times for $5 \mathrm{~min}$ with TBST buffer. Target proteins were detected using enhanced chemiluminescence (ECL). Images of bands were determined using Molecular Image ${ }^{\circledR}$ ChemiDoc $^{\mathrm{TM}} \mathrm{XRS}^{+}$with Image Lab ${ }^{\mathrm{TM}}$ Software (Bio-Rad Laboratories, Inc., USA.)

\section{Immunofluorescence staining}

EA.hy 926 cells were plated on small circular slides respectively with $50 \%$ confluent and serum starved overnight, and then treated with IL-8 for various concentrations (50, 100 and $200 \mathrm{ng} / \mathrm{ml}$ ) and durations (2, 4, 6 and $8 \mathrm{~h})$, respectively. Then cells were washed twice each with PBS for $5 \mathrm{~min}$, fixed with $4 \%$ paraformaldehyde in PBS for $8 \mathrm{~min}$, washed three times each with PBS for $5 \mathrm{~min}$. Cells were pre-incubated with 1\% BSA in PBS for 15 min to decrease non-specific antibody binding and washed for 30s to 1 min with PBS. Primary antibodies incubation (Occludin and ZO-1, E-cadherin and N-cadherin) was performed at $4^{\circ} \mathrm{C}$ overnight and slides were washed for 5 min with PBS for 3 times, and further incubated for $90 \mathrm{~min}$ in FITC-conjugated goat anti-mouse antibody and PE-conjugated goat anti-rabbit antibody, and then incubated with DAPI $\left(4^{\prime}\right.$ $6^{\prime}$-diamidino-2-phenylindole) that stained nuclei for $30 \mathrm{~min}$ at $37^{\circ} \mathrm{C}$. Samples were sealed by $10 \%$ glycerol, kept from light and observed by laser scanning confocal microscope (Leica TCS SP5, Germany).

\section{Statistical analysis}

All experiments repeated 3 times at least $(n=3)$. Means, together with standard deviations, were calculated for the experimental and control groups. One-Way ANOVA with Duncan's new multiple range method was performed by using data analysis software of SPSS12.0 (SPSS, Inc., Chicago, Illinois). The results were expressed as means \pm S.D. The $P$ values were calculated to test the level of statistical significance. The differences were considered significant at $P<0.05$.

\section{Results}

\section{IL-8 induced changes of endothelial permea- bility in dose- and time-dependent manners}

The tightness degree of the tight junctions was evaluated by Transwell assay. Endothelial monolayer were cultured in Matrigel-coated transwells and treated with IL-8. FITC-labeled bovine serum albumin was penetrated due to increased endothelial permeability induced by IL-8. The fluorescence intensity was quantified and permeability coefficient $\left(P_{a}\right)$ was calculated according to the formula in previous section, and the results were showed in Fig.1. It could be seen that the permeability coefficient, $P_{a}$, was gradually increased with the concentration (from 0 to 200 ng/ml, Fig.1A) and duration (from 0 to $8 \mathrm{~h}$, Fig.1B) of IL-8. Under the concentration of $100 \mathrm{ng} / \mathrm{ml}$ and 200 $\mathrm{ng} / \mathrm{ml}$ IL-8 stimulated for $4 \mathrm{~h}$, the $P_{\mathrm{a}}$ was higher than that under 0 (as controls) and $50 \mathrm{ng} / \mathrm{ml}(P<0.05)$. As to different treated duration, the $P_{\mathrm{a}}$ under $100 \mathrm{ng} / \mathrm{ml}$ IL-8 stimulated for 4, 6, $8 \mathrm{~h}$ was higher than that under 
stimulated for $0 \mathrm{~h}$ (controls) and $2 \mathrm{~h}(P<0.05)$, respectively. These results confirmed the change of endothelium permeability stimulated by IL- 8 exhibited dose and time-dependent manners.

\section{The morphological cell-cell junction changes of endothelium stimulated by IL-8}

The morphologic changes of endothelial permeability with different concentrations of IL-8 were observed by laser confocal microscopy. After the IL-8 concentration increased from 50 to $200 \mathrm{ng} / \mathrm{ml}$, gaps were observed between adjacent endothelial cells, correlating increased endothelial permeability with gap formation (white arrows indicated in Fig.2). We further checked the gap at cell-cell junctions by TEM observation, and the elevated distance could be clearly found with increase of concentration and treated duration of IL-8 among single cells (black arrows indicated in Fig.3). Based on the physical and morphological results, both dose and time-dependent manners were concluded in IL-8 induced endothelial permeability.

\section{IL-8-induced permeability is dependent upon down-regulation of $\mathrm{mRNA}$ and proteins of tight junction}

We supposed that IL-8-induced permeability was dependent upon regulation of tight junction proteins. Three classes of proteins are known to lo-

$$
\text { A }
$$

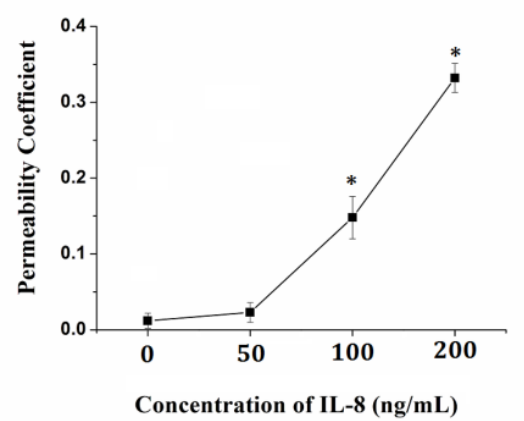

calize to tight junctions, including claudins, occludin and junction adhesion molecules. The claudin expression is highly restricted to specific regions of different tissues and may have an important role in transcellular transport through tight junctions. Occludin is an integral membrane protein closely associated with the tight junctions of endothelial cells. Therefore, the mRNA and proteins expression of occludin, claudin-5 and ZO-1 were investigated.

To determine the effect of IL- 8 with different concentrations and treated durations on mRNA and proteins expression of specific tight junction components, cells were exposed to 50, 100, $200 \mathrm{ng} / \mathrm{ml}$ IL-8 for $2 \mathrm{~h}$, and $100 \mathrm{ng} / \mathrm{ml} \mathrm{IL-} 8$ for 2, 4, 6 8h, respectively. The mRNA and proteins expression level of occludin, claudin-5 and ZO-1 were further examined by RT-PCR and Western blotting analysis, respectively. Fig.4A showed the effect of IL-8 with various treated durations (from $2 \mathrm{~h}$ to $8 \mathrm{~h}$ ) and concentrations (from 50 to $200 \mathrm{ng} / \mathrm{ml}$ ) on mRNA expression of occludin, claudin-5 and ZO-1. According to the PCR bands in Fig.4A, it could be found the endothelial cells treated with increased concentration of IL-8 down-regulated the mRNA expression of occludin, claudin-5 and ZO-1, and the increased treated duration of IL-8 also showed significant decrease mRNA expression of these proteins (Fig.4B, C and D).

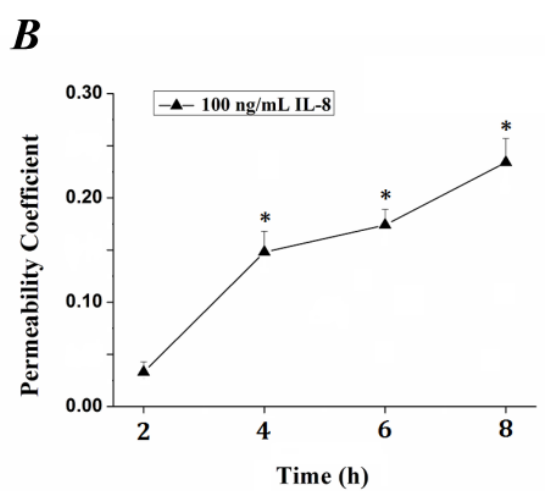

Fig.I The changes of endothelial permeability induced by IL-8 exhibited dose- and time-dependent manners. Permeability assay was perform as depicted in 2.1 , and coefficient $\left(P_{a}\right)$ in groups was calculated by formula $P_{a}=\left[C_{a}\right] / t \times 1 / S \times V /\left[C_{1}\right]$. (A) The transwell cultured with endothelium were treated with 50 , 100 and $200 \mathrm{ng} / \mathrm{ml} \mathrm{IL-8,} \mathrm{respectively.} \mathrm{(B)} \mathrm{The} \mathrm{transwell} \mathrm{cultured} \mathrm{with} \mathrm{endothelium} \mathrm{were} \mathrm{treated} \mathrm{with} 200 \mathrm{ng} / \mathrm{ml} \mathrm{IL-8} \mathrm{for} 2,4,6$ and $8 \mathrm{~h}$, respectively. Values represented the mean \pm S.E $(n=3) . *, P<0.05$ denoted statistically significant difference compares to control.

Control

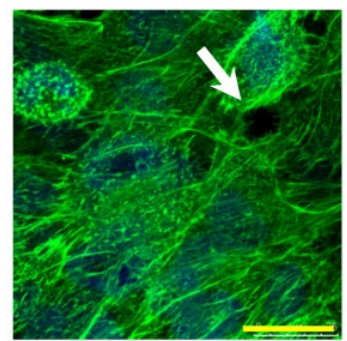

$50 \mathrm{ng} / \mathrm{ml}$

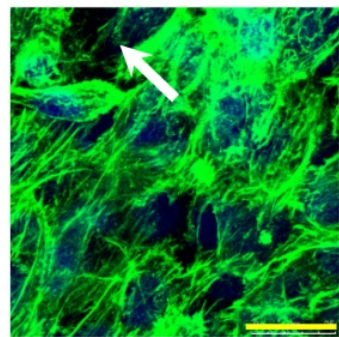

$100 \mathrm{ng} / \mathrm{ml}$

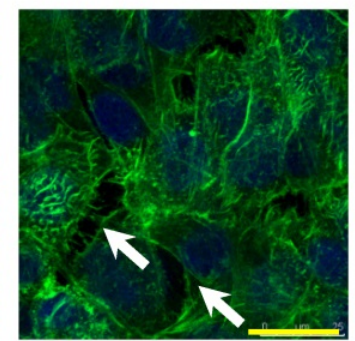

$200 \mathrm{ng} / \mathrm{ml}$

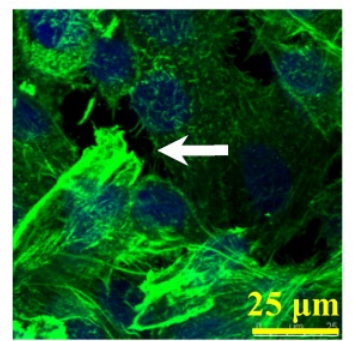

Fig. 2 Cultured cells treated with 0 (as controls), 50, 100 and $200 \mathrm{ng} / \mathrm{ml} \mathrm{IL-8} \mathrm{for} 4 \mathrm{~h}$ were stained with F-actin, and examined by laser confocal microscopy. The white arrows in figures showed visible cell-cell gaps formation. Scale bar in all images $=25 \mu \mathrm{m}$. 
Control

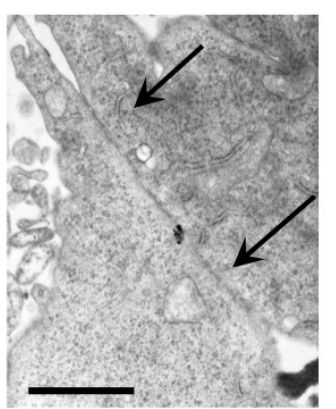

$50 \mathrm{ng} / \mathrm{ml}$ for $4 \mathrm{~h}$

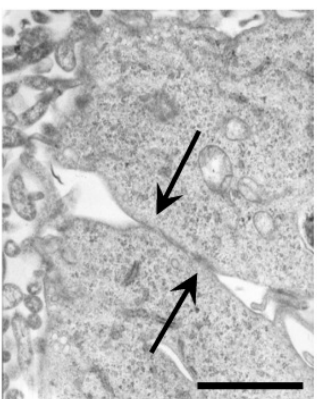

$200 \mathrm{ng} / \mathrm{ml}$ for $4 \mathrm{~h}$

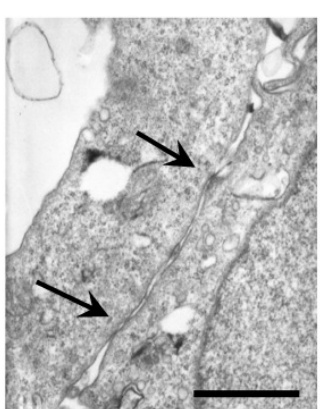

$100 \mathrm{ng} / \mathrm{ml}$ for $2 \mathrm{~h}$

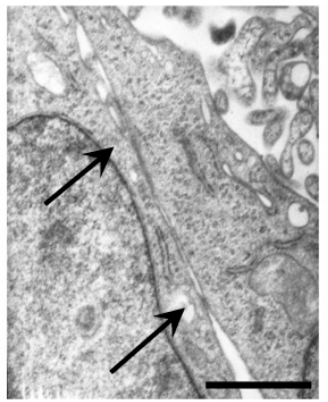

$100 \mathrm{ng} / \mathrm{ml}$ for $4 \mathrm{~h}$

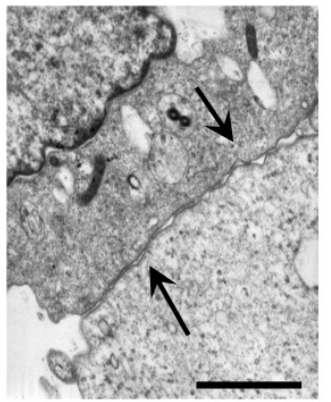

$100 \mathrm{ng} / \mathrm{ml}$ for $6 \mathrm{~h}$

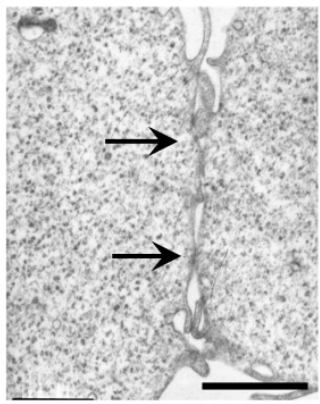

$100 \mathrm{ng} / \mathrm{ml}$ for $8 \mathrm{~h}$

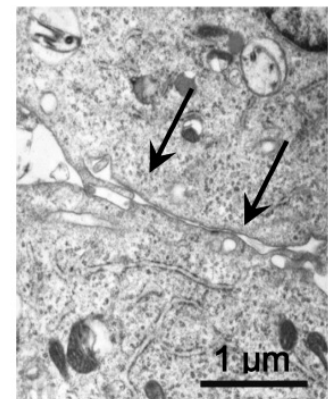

Fig.3 TEM images showed the different concentrations $(50,100$ and $200 \mathrm{ng} / \mathrm{ml})$ and treated durations $(2,4,6$ and $8 \mathrm{~h})$ of IL-8 on cell-cell junctions morphology. The black arrows in figures showed the junctions and gaps between two cells. Scale bar in all images $=1 \mu \mathrm{m}$.

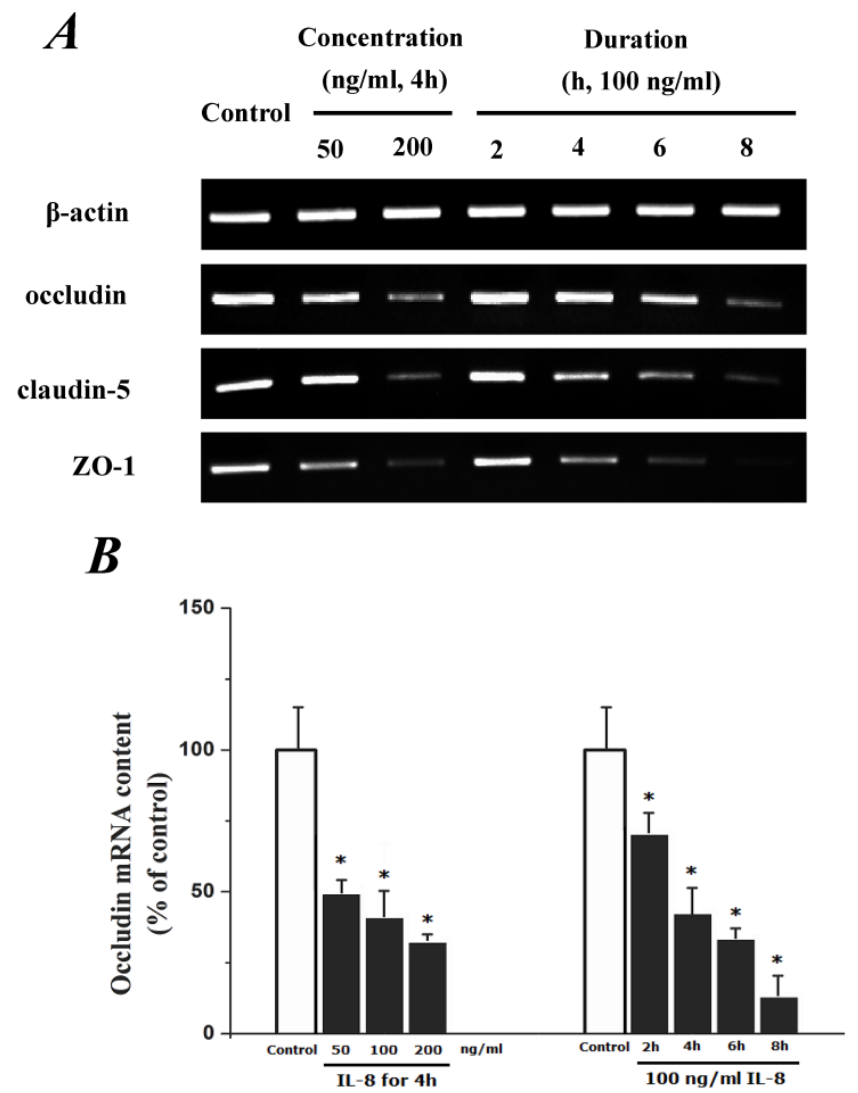

C

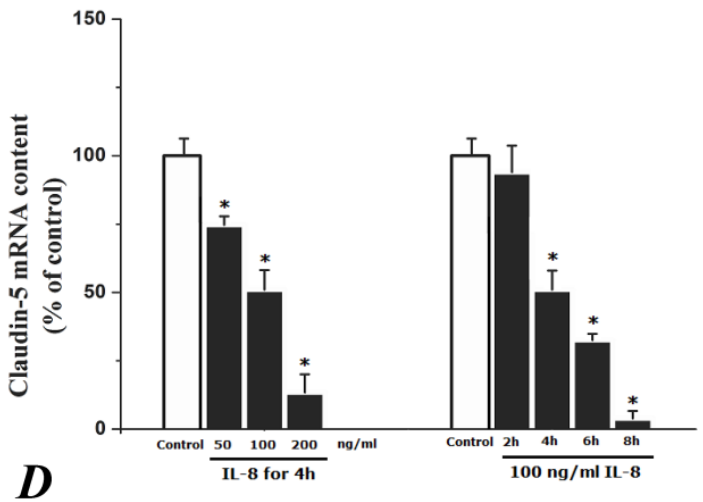

$\boldsymbol{D}$

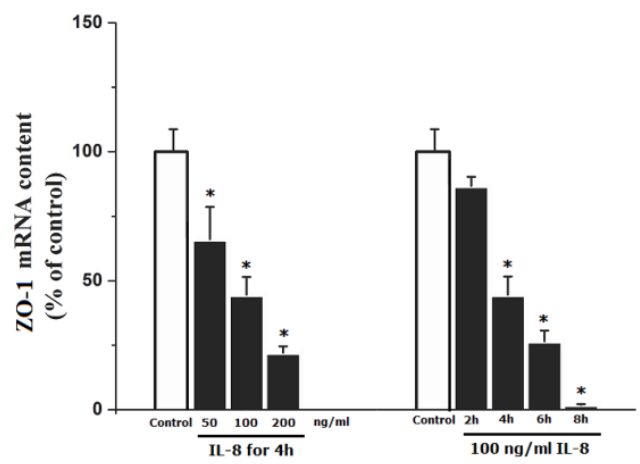

Fig.4 The effect of IL-8 on occludin, claudin-5 and ZO-I mRNA expression. IL-8 induced tight junction permeability in endothelium with decreased mRNA level of occludin, claudin-5 and ZO-I in a dose- and time-dependence manner. (A) Representative bands of tight junction mRNA expression. (B), (C) and (D) The level of $\beta$-actin in each group was used as intrinsic controls, and relative expression mRNA of occludin, claudin-5 and ZO-I were calculated, respectively. Values represented the mean $\pm S . D$. $(n=3)$. *, $P<0.05$ denoted statistically significant difference compares to control. 
The expression levels of Occludin, Claudin-5 and ZO-1 proteins were further determined by Western blotting, and the results were showed in Fig.5. Similar to the results of mRNA expression, the expression level of Occludin, Claudin- 5 and ZO-1 proteins decreased with higher concentration and longer duration of IL-8, and showed a dose- and time-dependence (Fig.5A). With increased treated concentration to $100-200 \mathrm{ng} / \mathrm{ml}$, the expression level of Occludin, Claudin-5 and ZO-1 proteins are weaker than that of control (Fig.5 B, C\&D). As to treated duration, 100 $\mathrm{ng} / \mathrm{ml}$ IL-8 significantly decreased Occludin after $4 \mathrm{~h}$ $(P<0.05$, Fig. 5E), and IL-8 reduced Claudin-5 expression at $4,6,8 \mathrm{~h}$ showed a significant difference compare to control $(0 \mathrm{~h})$ and $2 \mathrm{~h}(P<0.05$, Fig. $5 \mathrm{~F})$; only ZO-1 expression level showed a significant difference compare to control from initial $2 \mathrm{~h}$ (Fig.5G). Furthermore, the distribution of Occludin and ZO-1 in dif- ferent concentration of IL-8 treatment was examined by double immunofluorescence staining (Fig. $5 \mathrm{H}$ ). The expression levels of Occludin and ZO-1 were consistent with the results of Western blot. It could be found that the Occludin (green) and ZO-1 (red) localized at the cell border in control group, and IL-8 significantly decreases tight junction contents. Under IL-8 treatment, a loss of Occludin and ZO-1 was found, showing that the effect of IL-8 on Occludin was more pronounced. The ZO-1 showed the decreased level but still distributed at the edge of cells (200 $\mathrm{ng} / \mathrm{ml}$ group in Fig. $5 \mathrm{H}$ ), while a diffuse cytoplasmic distribution of Occludin was gradually observed in cells with increased concentration of IL-8. These results confirmed that IL-8 induced permeability is dependent upon down-regulation of mRNA and proteins of tight junctions.
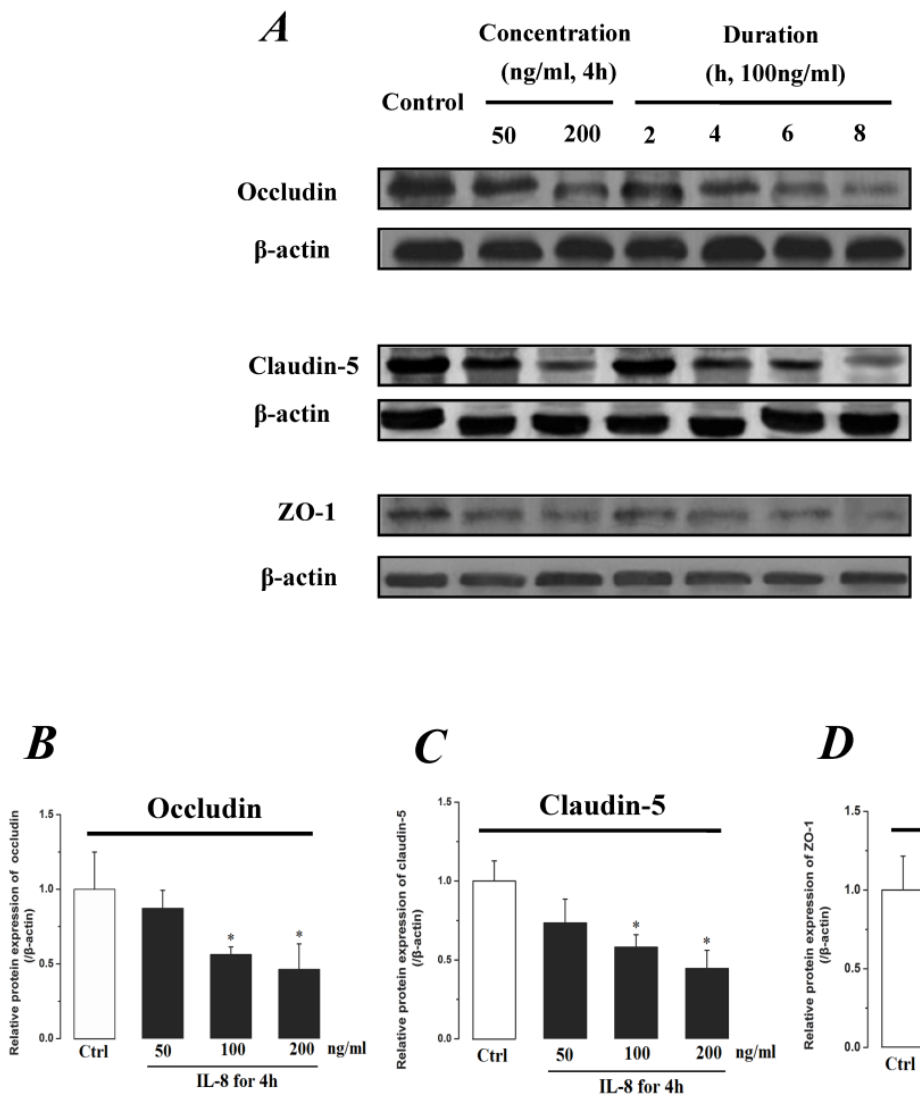

C

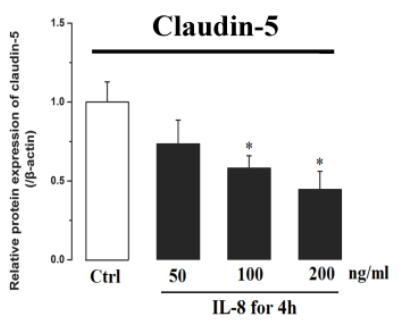

$\boldsymbol{F}$

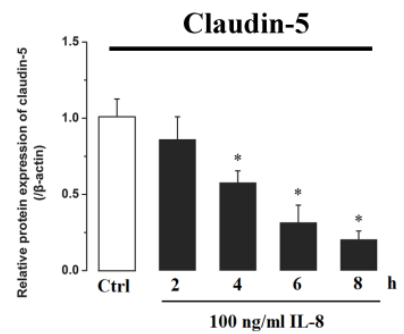

D

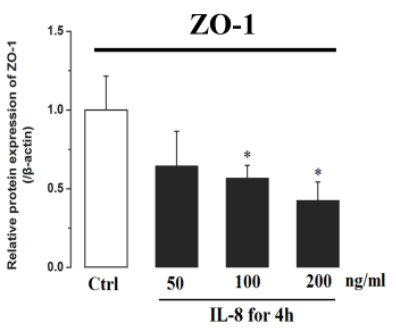

G

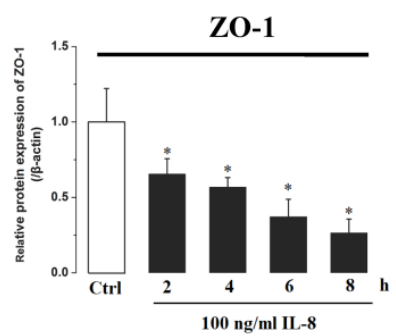




\section{$\boldsymbol{H}$}
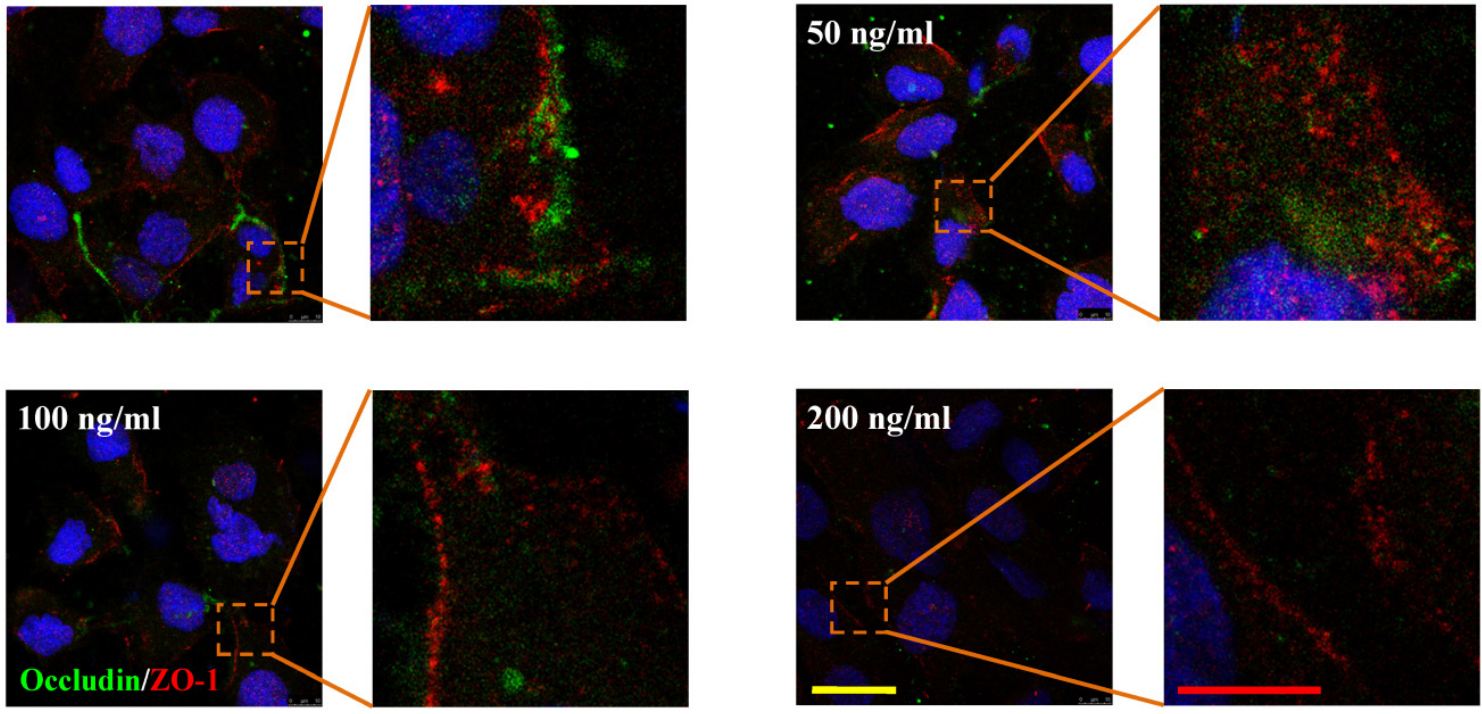

Fig.5 The effect of IL-8 with different concentrations and treated durations on the protein expression and distribution of tight junction contents. IL-8 induces tight junction permeability in endothelium with decreased expression level of Occludin, Claudin-5 and ZO-I. (A) Representative western blot of tight junction proteins expression. Quantification of each protein expression level by image analysis of the western blot bands in fig A. The expression level of $\beta$-actin in each group was used as intrinsic controls, and relative expression were calculated. (B-D) The expression level of Occludin, Claudin-5 and ZO-I with different doses of IL-8 (50, I00 and $200 \mathrm{ng} / \mathrm{ml}$ ) for $2 \mathrm{~h}$. (E-G) The expression level of Occludin, Claudin-5 and ZO-I with $100 \mathrm{ng} / \mathrm{ml}$ IL-8 for 2, 4, 6 and $8 \mathrm{~h}$, respectively. Values represented the mean \pm S.D. $(n=3)$. * $P<0.05$ denoted statistically significant difference compared to control. $(H)$ Double-labeled immunofluorescence analyzed the effects of increased concentration of IL-8 on distribution and expression of ZO-I (red) and Occludin (green) proteins, enlarged images of designated regions, labeled by square frames (blue: DAPIstained nucleus). Yellow scale bar $=25 \mu \mathrm{m}$.

\section{IL-8 down-regulated E-Cadherin but not N-Cadherin}

The cadherin, major members of $\mathrm{Ca}^{2+}$-dependent adhesion molecules that form adherent junctions and function to mediate cell-cell binding critical to the maintenance of tissue structure. E-cadherin (E-Cad) and $\mathrm{N}$-cadherin $(\mathrm{N}-\mathrm{Cad})$ share many structural and functional features, which establish $\mathrm{Ca}^{2+}$-dependent homophilic cell-cell adhesion with their extracellular domains and connect with catenin at their intracellular domains [21]. In this study, the effect of increased IL-8 concentration on expression and distribution of E-Cad and N-Cad was examined by immunofluorescence. As shown in Fig.6, increased dose of IL-8 could markedly reduce the expression of E-Cad, but did not affect N-Cad expression. There are no obvious changes of localization could be found. The result suggested that potential effect of IL-8 mediating endothelial permeability by down-regulation of adherent junction.

\section{IL-8-induced permeability was not dependent upon integrins-FAs pathway}

Integrin, which is a family of extracellular matrix receptors, transduces signaling from the outside ECM to the inside cell and regulate many aspects of cell behavior. Integrins are bound to ECM at specific cellular sites, named "focal contacts" or "focal adhe- sions" that are responsible for the adhesive interactions of the endothelial cell monolayer with ECM. The integrin $\alpha 2 \beta 1, a 5 \beta 1$ and $a v \beta 3$, the primary receptors of $\mathrm{VN}, \mathrm{FN}, \mathrm{LN}$ and Col, are widespread in many cells. The integrins mediate dynamic interactions between the extracellular matrix and the actin cytoskeleton. In this study, the effect of IL- 8 on the expression of integrins subunits $\alpha 2, a 5, \beta 1$ and $\beta 3$ were respectively examined, and the results were showed in Fig.7. It could be seen from Fig.7, there was no significant difference of integrin subunits ( $\alpha 2, a 5, \beta 1$ and $\beta 3$ ) expression level among all samples under increased concentration $(P>0.05$, Fig.7 B, C, D \& E) and treated duration $(P>0.05$, Fig.7 F, G, H \& I) of IL-8.

We further investigated the actin cytoskeleton by integrin cytoplasmic tail $\beta$ binding proteins (Talin, Vinculin and Paxillin), which formed focal adhesions (FAs) cytoplasmic plaque implicated in regulation of the actin cytoskeleton (Fig.8). The phosphorylation of Paxillin upon integrin engagement or growth factor stimulation can create binding sites for the adapter protein and localize to focal adhesion. It could be found that the expression level of FA components exhibited less difference $(P>0.05)$ with incremental concentration (Fig. 8 B, C\&D) and treated duration (Fig.8 E, F, \&G) of IL-8. The ratio of phosphorylated Paxillin ( $p$ Pax) in total Paxillin also showed less difference with various concentrations and durations of 
IL-8 treatment (Fig.8 H\&I). These results suggested that the increased endothelial permeability induced by IL-8, was not dependent upon integrins-FAs pathway, and that IL-8 could not regulate the ECM and its interactions with the endothelium.
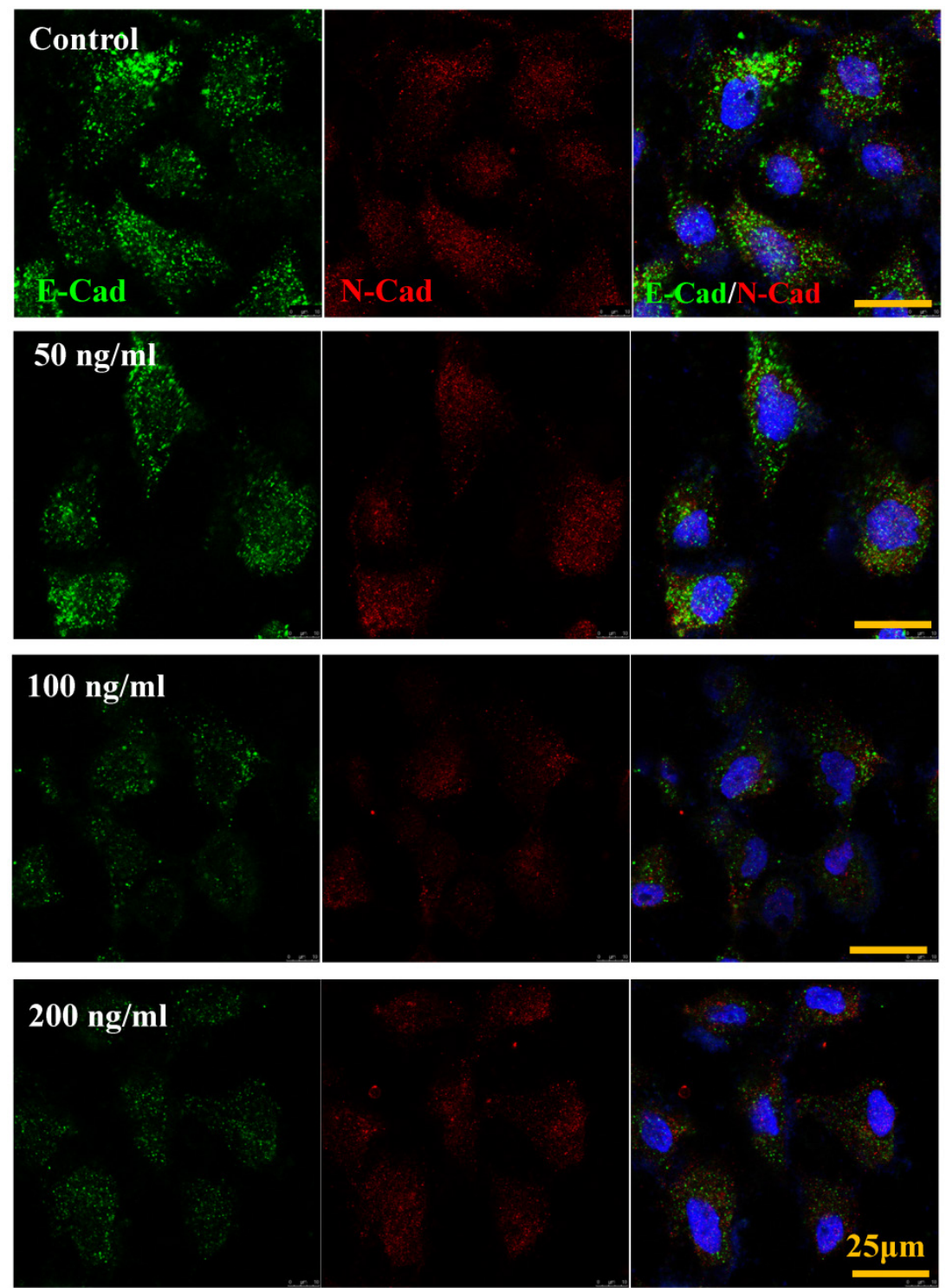

Fig.6 IL-8 regulated the expression and distribution of E-Cad and N-Cad. Double-labeled immunofluorescence analyzed the effects of increased concentration (from 0 to $200 \mathrm{ng} / \mathrm{ml}$ ) of IL-8 on distribution and expression of E-Cad (green) and N-Cad (red) proteins. (blue: DAPI stained nucleus). Yellow scale bar = $25 \mu \mathrm{m}$. 
A

Concentration Duration

\begin{tabular}{|c|c|c|c|c|c|c|}
\hline \multirow{2}{*}{ Control } & \multicolumn{2}{|c|}{ (ng/ml, 4h) } & \multicolumn{4}{|c|}{ (h, $100 \mathrm{ng} / \mathrm{ml})$} \\
\hline & 50 & 200 & 2 & 4 & 6 & 8 \\
\hline
\end{tabular}

$\beta$-actin

Integrins $\alpha 2$

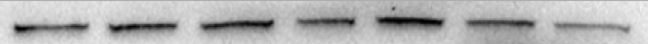

$\alpha 5$

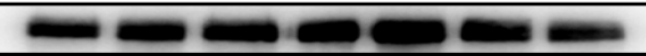

$\beta 1$

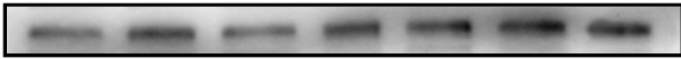

B3

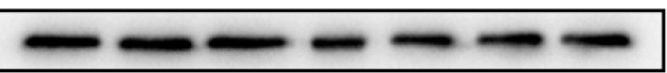

B

C

D

$\boldsymbol{E}$
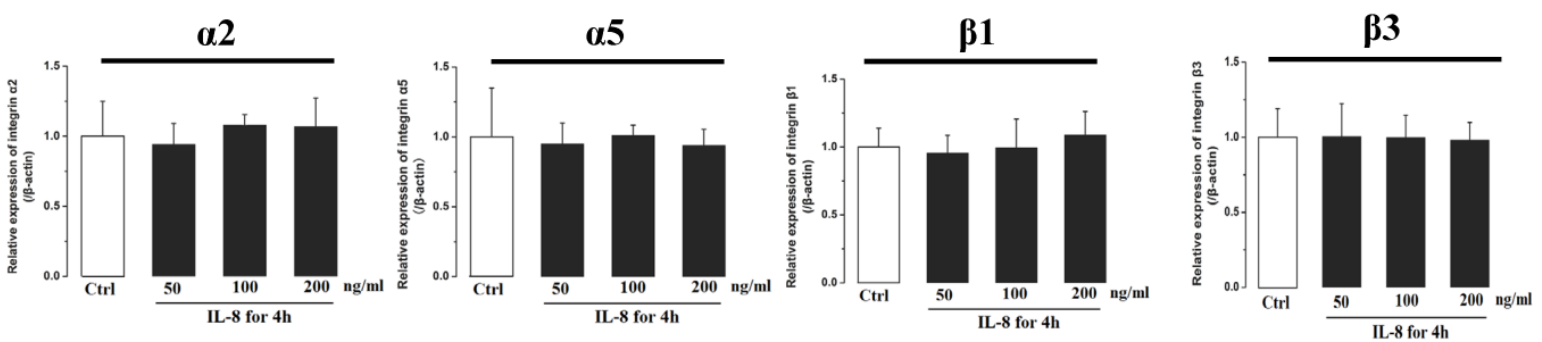

$\boldsymbol{F}$

G

H
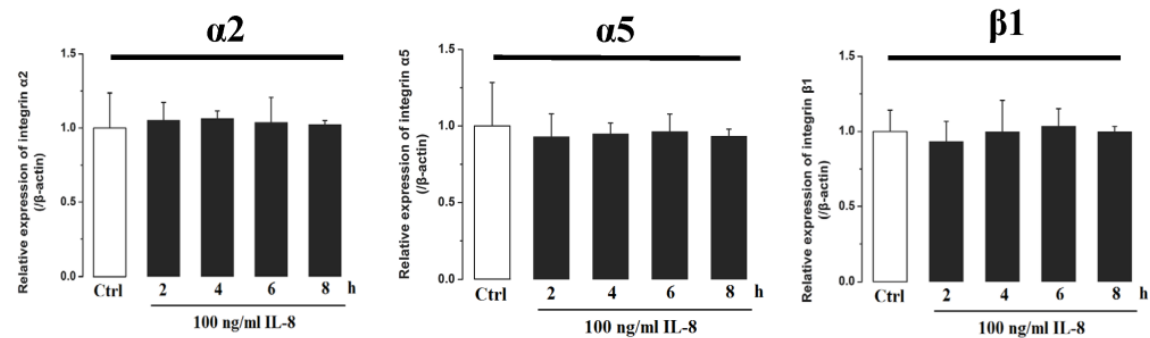

I

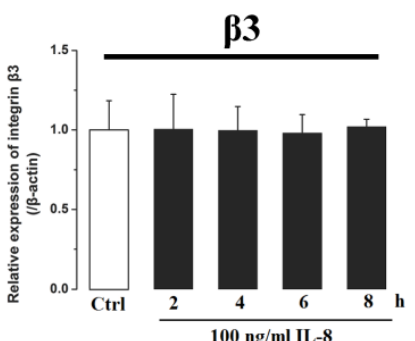

Fig.7 The effect of IL-8 on the protein expression level of Integrin subunits, $\alpha 2, \alpha 5, \beta I$ and $\beta 3$. There were not significant differences of expressions level of Integrin subunits treated by either concentration or duration of IL-8. (A) Representative Western blot bands of integrins expression. Quantification of each protein expression level by image analysis of the Western blot bands in fig A. The relative expression were calculated by expression level of $\beta$-actin in each group as intrinsic controls. (B-E) The expression level of Integrin subunits, $\alpha 2, \alpha 5, \beta 1$, and $\beta 3$ with different doses of IL-8 (50, 100 and $200 \mathrm{ng} / \mathrm{ml}$ ) for $2 \mathrm{~h}$. (F-I) The expression level of Integrin subunits, $\alpha 2, \alpha 5, \beta I$, and $\beta 3$ with $100 \mathrm{ng} / \mathrm{ml} \mathrm{IL-8}$ for $2,4,6$ and $8 \mathrm{~h}$, respectively. Values represented the mean $\pm S . D$. $(n=3)$. *, $P<0.05$ denoted statistically significant difference compared to control. 


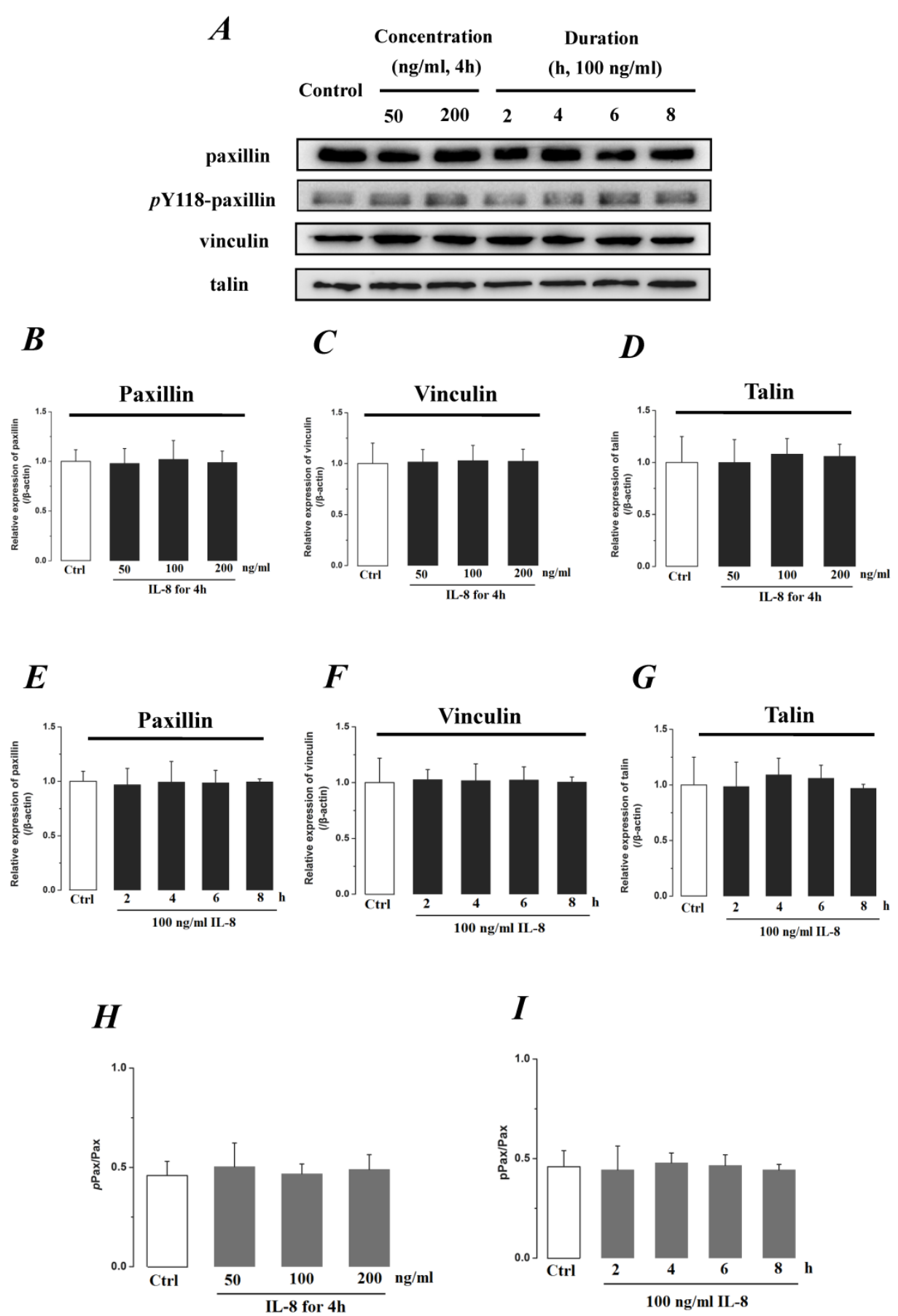

Fig.8 The effect of IL-8 on the protein expression of focal adhesion components, Paxillin, Vinculin and Talin. The expression levels of Paxillin, Vinculin and Talin were not changed by either concentration or duration of IL-8. (A) Representative Western blot bands of integrins expression. Quantification of each protein expression level by image analysis of the Western blot bands in fig A. The expression level of $\beta$-actin in each group was used as intrinsic controls, and relative expression were calculated. (B-D) The expression level of focal adhesion components, Paxillin, Vinculin and Talin with different doses of IL-8 (50, $100 \mathrm{and} 200 \mathrm{ng} / \mathrm{ml})$ for 2h. (E-G) The expression level of focal adhesion components with $100 \mathrm{ng} / \mathrm{ml} \mathrm{IL-8} \mathrm{for} \mathrm{2,} \mathrm{4,} 6$ and 8h, respectively. (H \& I) The ratios of phosphorylated Paxillin $(p \operatorname{Pax})$ in total Paxillin (Pax) with different doses and treated durations of IL- 8 were calculated and compared. Values represented the mean $\pm S . D$. $(n=3)$.

\section{Discussion}

The vascular endothelial cell monolayer is localized at the critical interface between the blood and vessel wall, which has the vital functions of regulating balance and supplying the essential nutrients needed for the survival of the organism. The endothelium, which is composed of vascular endothelial cells, plays a central role in maintaining the vascular homeostasis by releasing endothelium-derived relaxing factor including prostacyclin (PGI2), nitric oxide (NO), and endothelium-derived contracting factor including platelet-activating factor (PAF) and endothelin-1 (ET-1) [22]. The semi-permeable barrier of cell-cell 
junction could maintain exchange of macromolecules between the blood and tissue through interstitial space, which could be regulated by a lot of mediators such as thrombin, TNF-a, LPS, and chemokines [23]. IL-8 is one of chemokines produced by macrophages and some epithelial cells. The primary biological effects of IL-8 are to recruit neutrophils to phagocytose the antigen, which triggers the antigen pattern toll-like receptors. Elevated levels of IL-8 have been found at site of injured endothelium and atherosclerotic plaque [24]. In our previous studies, it was found that IL-8 could induce the expression changes of Rac1 and RhoA in a time-dependent way, mediate cytoskeletal rearrangement and regulate the ECs migration through the activation of phosphoinositide 3-kinase (PI3K)-Rac1/RhoA pathway [25], and that laminar shear stress could increase the mRNA level of IL-8 in a CXC chemokine receptors (CXCR1/CXCR2)-dependent way [26]. Jovanovic et al [16] proved that IL-8 could regulate trophoblast cell (HTR-8/SVneo) migration in a dose-dependent way (from 0.5 to $5 \mathrm{ng} / \mathrm{ml}$, but decreased with $10 \mathrm{ng} / \mathrm{ml}$ IL-8 addition) and increase expression levels of Integrins a5 and $\beta 1$ subunits. Lee et al [27] found that knockdown of IL-8 could inhibit the migratory ability and decrease integrins $\mathrm{aV}$ and $\beta 3$ expression in human chondrosarcoma cells lines (JJ012 and SW1353). In addition, it has been reported that Integrins (e.g. $a V, a 3, a 4, \beta 1, \beta 5)$ participated in change of vascular permeability and endothelial barrier function by some drugs and growth factors such as cilengitide [28], pseudomonas aeruginosa [29], and VEGF [30-31]. However, in this study, our results showed that the expression levels of Integrins $\alpha 2, \alpha 5, \beta 1$ and $\beta 3$ were not changed with the concentration and duration of IL-8 addition, suggesting that the endothelial permeability regulated by IL-8 did not depend on integrins-induced signals. The possible reason is that different cell types result in inconsistent conclusions. In addition, recent studies showed that IL-8 signals played an essential role of acquisition and/or maintenance of the mesenchymal and invasive features in the epithelial-mesenchymal transition (EMT) of human carcinoma cells [32], and down-regulation of tight junction is associated with EMT in cancer cells [33].

Emerging findings indicate that IL-8 promotes endothelial permeability by initiating the activation of CXCR2 [34], which could stimulate VEGFR phosphorylation in a transactivation manner [19]. CXCR2 or VEGFR enhanced endothelial permeability via PI3K/Akt, Rho/Rock activation, actin polymerization and phosphorylations of VE-cadherin and Occludin, resulting in opening of adherent junctions and tight junctions [35]. The activation of the PI3K/Akt path- way that inhibits GSK- $3 \beta$ blocking $\beta$-catenin and snail involved in EMT, and represses the expression of E-cadherin and tight junction [36]. IL-8 stimulates PI3K through its G protein-linked receptor, CXCR2, providing a specific molecular targeted intervention in vascular permeability [37]. The growth factor, VEGF has also been found that it induced Occludin degradation and regulated its phosphorylation and ubiquitination, but showed no effect on expression of claudin-5 [10]. Interleukin-6 (IL-6) is also an interleukin that acts as both a pro-inflammatory and anti-inflammatory cytokine. Suzuki et al demonstrated IL-6 could increase Claudin-2 expression and regulate tight junction permeability in intestinal epithelium [11]. Tai et al found that amyloid- $\beta$ could down-regulate Occludin and increase permeability in human brain endothelial cells via MAPK signaling pathway, which is associated in vascular dysfunction of blood-brain barrier in Alzheimer's disease [38]. Nag S. et al also demonstrated that blood-brain barrier breakdown showed a marked increase of caveolin-1, loss of Occludin and reduced localization of Claudin-5, and increased expression of caveolin-1 preceded the decreased expression of Occludin and Claudin-5 in tight junction [39]. In addition, both IL-1 $\beta$ and TNF- $\alpha$ increased permeability in bovine retinal endothelial cells (BREC), and TNF-a signals significantly decreased the protein and mRNA of the tight junction proteins ZO-1 and Claudin-5, and altered the cellular localization of these tight junction proteins through $\mathrm{PKC} / \mathrm{NF}-\mathrm{KB}$ pathway [9], while IL-1 $\beta$ could increase intestinal epithelial tight junction permeability by an NF-kB-dependent increase in myosin $\mathrm{L}$ chain kinase (MLCK) gene transcription [40], which is mediated by MEK kinase (MEKK-1) in a canonical NF-kB pathway and NFKB inducing kinase (NIK) in an activation of the noncanonical NF-KB pathway [41].

The permeability of the vascular barrier can be modified in response to specific stimuli acting on endothelial cells. As significant structural foundation of endothelial permeability, cell junctions consist of multi-protein complexes that provide contact between neighboring cells or between a cell and the extracellular matrix. There are three major types of cell junctions: adherent junctions, desmosomes and hemidesmosomes (anchoring junctions), gap junctions (communicating junction) and tight junctions (occludin junctions) [7]. Tight junctions are the closely associated areas of two cells whose membranes join together forming a virtually impermeable barrier to fluid, which consist of some different peripheral membrane proteins located on the intracellular side of plasma membrane and regulate the passage of ions and molecules through the paracellular pathway in 
epithelial and endothelial cells. The major types are Claudins and Occludins, which could anchor the strands to the actin component of the cytoskeleton, was used in this study to investigate enhancement of paracellular permeability and damage of tight junction with IL-8 introduction. In present study, the underlying mechanisms the effects of IL-8 on endothelial permeability were studied, and the results demonstrated that IL-8 down-regulated tight junction proteins expression, which was associated with an increase in endothelial permeability. Occludin, Claudin-5 and ZO-1 are widely studied, which contribute to alterations in endothelial permeability in response to inflammatory cytokines. However, the expression level and cellular location of Occludin, Claudin-5 and ZO-1 coupled with increase of endothelial permeability are different in various cell lines. Nag S. et al demonstrated that blood-brain barrier breakdown showed a marked loss of Occludin and reduce of localization of Claudin-5 [39]. Aveleira et al indicated that TNF-a increased permeability with a decrease of the protein and mRNA of ZO-1 and Claudin-5, but increased level of Occludin [9]. While Noth et al observed a down-regulation of Occludin without any changes in ZO-1 with an increased paracellular permeability in a murine model of acute graft versus host disease of the small intestine [42]. Tai et al found that amyloid- $\beta$ could down-regulate Occludin with increased permeability in human brain endothelial cells [38]. However, we found in this study that IL-8 could down-regulate the levels of Occludin, Claudin- 5 and ZO-1 in a dose- and time-dependent manner, which contributed to increase of endothelial permeability. The reason for difference of Occludin, Claudin-5 and ZO-1 expression may be related to differences in cell types and conditions of cell culture.

Integrin cytoplasmic tail $\beta$ binding FAs provides an important structural basis for anchoring the endothelial lining to its surrounding matrices in the vascular wall. The assembly of FAs serves as important signaling events in modulating endothelial permeability under stimulatory conditions including angiogenic factors, inflammatory mediators, or physical forces [43]. Focal adhesion kinase (FAK) is a non-receptor tyrosine kinase functions as the engagement of integrins and assembly of FAs through the catalyzing of several downstream signals and mediates cell behaviors [44]. Integrin- and growth factor-stimulated cues are significant events for activating FAK [45]. It has been found that the endothelial permeability could be regulated by various factors such as transforming growth factor- $\beta$ (TGF- $\beta$ ) [46] and VEGF [47] invovled associated FAK signals. The $G$ protein subunits downstream of protease activated receptor 1 (PAR1) and sphingosine-1-phosphate receptor 1 (S1P1) could initiate phosphorylation of FAK and regulate endothelial barrier function [48]. Activated FAK stimulated by $\mathrm{S} 1 \mathrm{P}$, participates in rearrangement of actin cytoskeletal at the cell periphery, strengthens cell-matrix (FA) and cell-cell (adherens junction) junctional complex, and decreases vascular permeability [49]. In addition, previous reports also demonstrated that IL-8 could induce phosphorylation of FAK via IL-8 receptors CXCR1/CXCR2, and mediate cell migration [50]. Therefore, FAs components including Talin, Paxillin and Vinculin as FAK-binding partners were investigated in this study, and our results indicated that there were no significant differences among their expression level under IL-8 stimulation with different concentration and duration, suggesting that IL-8 regulating endothelial permeability was not dependent upon alteration of cell-matrix adhesions.

\section{Conclusion}

In this study, the endothelial permeability induced by IL- 8 and the mRNA and protein expression level of tight junction components (ZO-1, Claudin-5 and Occludin) were examined. We found that IL-8 regulated the permeability of endothelium by down-regulation of tight junction in a dose- and time-dependence manner. However, the expression levels of Integrins and focal adhesion components showed no significant difference with increased concentration and duration of IL-8 treatment, suggesting that IL-8 induced endothelial permeability may not be dependent upon adhesion behavior of cell-substrate. This finding reveals the molecular mechanism in the increase of endothelial cell permeability induced by IL-8, and it may lead to the development of new therapies that can be applied in pathological conditions involving increase in endothelial permeability.

\section{Acknowledgement}

This study was supported in part by grant from National Natural Science Foundation of China (No.11372203, 11172189 and 31300775), Visiting Scholar Foundation of Key Laboratory of Biorheological Science and Technology (Chongqing University), Specialized Research Fund for the Doctoral Program of Higher Education (20120181120058) and the National Science Foundation for Fostering Talents in Basic Research of the National Natural Science Foundation of China (J1103604).

\section{Competing Interests}

The authors have declared that no competing interest exists. 


\section{References}

1. Mehta D, Malik AB. Signaling mechanisms regulating endothelial permeability. Physiol Rev. 2006; 86: 279-367.

2. Siflinger-Birnboim A, Johnson A. Protein kinase C modulates pulmonary endothelial permeability: a paradigm for acute lung injury. Am J Physiol Lung Cell Mol Physiol. 2003; 284: L435-451.

3. Basu S, Sarkar C, Chakroborty D, Nagy J, Mitra RB, Dasgupta PS, Mukhopadhyay D. Ablation of peripheral dopaminergic nerves stimulates malignant tumor growth by inducing vascular permeability factor/vascular endothelial growth factor-mediated angiogenesis. Cancer Res. 2004; 64: 5551-5555.

4. Jeliazkova-Mecheva VV, Hymer WC, Nicholas NC, Bobilya DJ. Brief heat shock affects the permeability and thermotolerance of an in vitro blood-brain barrier model of porcine brain microvascular endothelial cells. Microvasc Res. 2006; 71: 108-114.

5. Pickkers P, Sprong T, Eijk L, Hoeven H, Smits P, Deuren M. Vascular endothelial growth factor is increased during the first 48 hours of human septic shock and correlates with vascular permeability. Shock. 2005; 24: $508-512$

6. Davignon J, Ganz P. Role of endothelial dysfunction in atherosclerosis. Circulation. 2004; 109(23 Suppl 1): III27-32.

7. Balda MS, Matter K. Tight junctions. J Cell Sci 111. 1998; ( Pt 5):541-547.

8. Matter K, Balda MS. Signalling to and from tight junctions. Nat Rev Mol Cell Biol. 2003; 4:225-236.

9. Aveleira CA, Lin CM, Abcouwer SF, Ambrosio AF, Antonetti DA. TNF-alpha signals through PKCzeta/NF-kappaB to alter the tight junction complex and increase retinal endothelial cell permeability. Diabetes. 2010; 59: 2872-2882.

10. Murakami T, Felinski EA, Antonetti DA. Occludin phosphorylation and ubiquitination regulate tight junction trafficking and vascular endothelial growth factor-induced permeability. J Biol Chem. 2009; 284: 21036-21046.

11. Suzuki T, Yoshinaga N, Tanabe S. Interleukin-6 (IL-6) regulates claudin-2 expression and tight junction permeability in intestinal epithelium. J Biol Chem. 2011; 286:31263-31271.

12. Nooteboom A, Hendriks T, Otteholler I, van der Linden CJ. Permeability characteristics of human endothelial monolayers seeded on different extracellular matrix proteins. Mediators Inflamm. 2000; 9:235-241.

13. Mierke CT, Kollmannsberger P, Zitterbart DP, Smith J, Fabry B, Goldmann WH. Mechano-coupling and regulation of contractility by the vinculin tail domain. Biophys J. 2008; 94: 661-670.

14. Waugh DJJ, Wilson C. The Interleukin-8 Pathway in Cancer. Clinical Cancer Research. 2008; 14: 6735-6741

15. Brat DJ, Bellail AC, Van Meir EG. The role of interleukin-8 and its receptors in gliomagenesis and tumoral angiogenesis. Neuro Oncol. 2005; 7: 122-133.

16. Jovanovic M, Stefanoska I, Radojcic L, Vicovac L. Interleukin-8 (CXCL8) stimulates trophoblast cell migration and invasion by increasing levels of matrix metalloproteinase (MMP)2 and MMP9 and integrins alpha5 and beta1. Reproduction. 2010; 139: 789-798.

17. Schraufstatter IU, Chung J, Burger M. IL-8 activates endothelial cell CXCR1 and CXCR2 through Rho and Rac signaling pathways. Am J Physiol Lung Cell Mol Physiol. 2001; 280: L1094-1103.

18. Papadopoulou C, Corrigall V, Taylor PR, Poston RN. The role of the chemokines MCP-1, GRO-alpha, IL-8 and their receptors in the adhesion of monocytic cells to human atherosclerotic plaques. Cytokine. 2008; 43: 181-186.

19. Petreaca ML, Yao M, Liu Y, Defea K, Martins-Green M. Transactivation of vascular endothelial growth factor receptor-2 by interleukin-8 (IL-8/CXCL8) is required for IL-8/CXCL8-induced endothelial permeability. Mol Biol Cell. 2007: 18: 5014-5023.

20. Tinsley JH, Wu MH, Ma W, Taulman AC, Yuan SY. Activated neutrophils induce hyperpermeability and phosphorylation of adherens junction proteins in coronary venular endothelial cells. J Biol Chem. 1999; 274: 24930-24934.

21. Gumbiner BM. Regulation of cadherin mediated adhesion in morphogenesis. Nat Rev Mol Cell Biol. 2005; 6(8): 622-634.

22 Urakami-Harasawa L, Shimokawa $\mathrm{H}$, Nakashima M, Egashira K, Takeshita A. Importance of endothelium-derived hyperpolarizing factor in human arteries. J Clin Invest. 1997; 100: 2793-2799.

23. Vandenbroucke E, Mehta D, Minshall R, Malik AB. Regulation of endothelial junctional permeability. Ann N Y Acad Sci. 2008; 1123: 134-145.

24. von der Thusen JH, Kuiper J, van Berkel TJ, Biessen EA. Interleukins in atherosclerosis: molecular pathways and therapeutic potential. Pharmacol Rev. 2003; 55: 133-166.

25. Lai $Y$, Shen $Y$, Liu XH, Zhang Y, Zeng Y, Liu YF. Interleukin-8 Induces the Endothelial Cell Migration through the Activation of Phosphoinositide 3-Kinase-Rac1/RhoA Pathway. Int J Biol Sci. 2011; 7: 782-791.

26. Zeng Y, Sun HR, Yu C, Lai Y, Liu XI, Wu J, Chen HQ, Liu XH. CXCR1 and CXCR2 are novel mechano-sensors mediating laminar shear stress-induced endothelial cell migration. Cytokine. 2011; 53: 42-51.

27. Lee $\mathrm{CY}$, Huang $\mathrm{CY}$, Chen MY, Lin $\mathrm{CY}$, Hsu HC, Tang $\mathrm{CH}$. IL-8 increases integrin expression and cell motility in human chondrosarcoma cells. J Cell Biochem. 2011; 112: 2549-2557.

28. Alghisi GC, Ponsonnet L, Ruegg C. The integrin antagonist cilengitide activates alphaVbeta3, disrupts VE-cadherin localization at cell junctions and enhances permeability in endothelial cells. PLoS One. 2009; 4: e4449.

29. Ganter MT, Roux J, Su G, Lynch SV, Deutschman CS, Weiss YG, Christiaans SC, Myazawa B, Kipnis E, Wiener-Kronish JP, Howard M, Pittet JF. Role of small GTPases and alphavbeta5 integrin in Pseudomonas aeruginosa-induced increase in lung endothelial permeability. Am J Respir Cell Mol Biol. 2009; 40: $108-118$.

30. Kim SH, Cho YR, Kim HJ, Oh JS, Ahn EK, Ko HJ, Hwang BJ, Lee SJ, Cho Y, Kim YK, Stetler-Stevenson WG, Seo DW. Antagonism of VEGF-A-induced increase in vascular permeability by an integrin alpha3beta1-Shp-1-cAMP/PKA pathway. Blood. 2012;120: 4892-902.

31. Robinson SD, Reynolds LE, Wyder L, Hicklin DJ, Hodivala-Dilke KM. Beta3-integrin regulates vascular endothelial growth factor-A-dependent permeability. Arterioscler Thromb Vasc Biol. 2004; 24: 2108-2114.

32. Fernando RI, Castillo MD, Litzinger M, Hamilton DH, Palena C. IL-8 signaling plays a critical role in the epithelial-mesenchymal transition of human carcinoma cells. Cancer Res.2011;71: 5296-5306.

33. Kojima T, Takasawa A, Kyuno D, Ito T, Yamaguchi H, Hirata K, Tsujiwaki M, Murata M, Tanaka S, Sawada N. Downregulation of tight junction-associated MARVEL protein marvelD3 during epithelial-mesenchymal transition in human pancreatic cancer cells. Exp Cell Res. 2011; 317: 2288-2298.

34. Dwyer J, Hebda JK, Le Guelte A, Galan-Moya EM, Smith SS, Azzi S, Bidere N, Gavard J. Glioblastoma cell-secreted interleukin-8 induces brain endothelial cell permeability via CXCR2. PLoS One. 2012;7:e45562.

35. Chen SU, Chou CH, Lin CW, Lee H, Wu JC, Lu HF, Chen CD, Yang YS. Signal mechanisms of vascular endothelial growth factor and interleukin-8 in ovarian hyperstimulation syndrome: dopamine targets their common pathways. Hum Reprod. 2010;25:757-767.

36. González-Mariscal L, Tapia R, Chamorro D. Crosstalk of tight junction components with signaling pathways. Biochim Biophys Acta. 2008;1778: 729-756.

37. Gavard I, Hou X, Qu Y, Masedunskas A, Martin D, Weigert R, Li X, Gutkind JS. A role for a CXCR2/phosphatidylinositol 3-kinase gamma signaling axis in acute and chronic vascular permeability. Mol Cell Biol. 2009;29(9):2469-2480 .

38. Tai LM, Holloway KA, Male DK, Loughlin AJ, Romero IA. Amyloid-beta-induced occludin down-regulation and increased permeability in human brain endothelial cells is mediated by MAPK activation. J Cell Mol Med. 2010; 14: 1101-1112.

39. Nag S, Venugopalan R, Stewart DJ. Increased caveolin-1 expression precedes decreased expression of occludin and claudin- 5 during blood-brain barrier breakdown. Acta Neuropathol. 2007; 114: 459-469.

40. Al-Sadi R, Ye D, Dokladny K, Ma TY. Mechanism of IL-1beta-induced increase in intestinal epithelial tight junction permeability. J Immunol. 2008; 180: 5653-5661.

41. Al-Sadi R, Ye D, Said HM, Ma TY. IL-1beta-induced increase in intestinal epithelial tight junction permeability is mediated by MEKK-1 activation of canonical NF-kappaB pathway. Am J Pathol. 2010; 177: 2310-2322.

42. Noth R, Lange-Grumfeld J, Stuber E, Kruse ML, Ellrichmann M, Hasler R, Hampe J, Bewig B, Rosenstiel P, Schreiber S, Arlt A. Increased intestinal permeability and tight junction disruption by altered expression and localization of occludin in a murine graft versus host disease model. BMC Gastroenterol. 2011; 11: 109

43. Wu MH. Endothelial focal adhesions and barrier function. J Physiol. 2005; 569:359-366

44. Wozniak MA, Modzelewska K, Kwong L, Keely PJ. Focal adhesion regulation of cell behavior. Bba-Mol Cell Res. 2004: 1692: 103-119.

45. Sieg DJ, Hauck CR, Ilic D, Klingbeil CK, Schaefer E, Damsky CH, Schlaepfer DD. FAK integrates growth-factor and integrin signals to promote cell migration. Nature Cell Biology. 2000; 2: 249-256.

46. Lee YH, Kayyali US, Sousa AM, Rajan T, Lechleider RJ, Day RM. Transforming growth factor-beta1 effects on endothelial monolayer permeability involve focal adhesion kinase/Src. Am J Respir Cell Mol Biol. 2007: 37: 485-493.

47. Chen XL, Nam JO, Jean C, Lawson C, Walsh CT, Goka E, Lim ST, Tomar A, Tancioni I, Uryu S, Guan JL, Acevedo LM, Weis SM, Cheresh DA, Schlaepfer DD. VEGF-induced vascular permeability is mediated by FAK. Dev Cell. 2012; 22: $146-157$

48. Thennes T, Mehta D. Heterotrimeric G proteins, focal adhesion kinase, and endothelial barrier function. Microvasc Res. 2012; 83: 31-44.

49. Belvitch P, Dudek SM. Role of FAK in S1P-regulated endothelial permeability. Microvasc Res. 2012; 83: 22-30.

50. Cohen-Hillel E, Yron I, Meshel T, Soria G, Attal H, Ben-Baruch A. CXCL8-induced FAK phosphorylation via CXCR1 and CXCR2: cytoskeletonand integrin-related mechanisms converge with FAK regulatory pathways in a receptor-specific manner. Cytokine. 2006; 3: 1-16 